The Journal of Nepalese Business Studies Vol. XIV No. 1 December 2021 ISSN 2676-1238 (Online)

(A Peer-Reviewed, Open Access Journal)

\title{
Determinants of Tax Compliance Behaviour among Rental Income Earners in Pokhara
}

\author{
Ghanashyam Tiwari*
}

DOI: https://doi.org/10.3126/jnbs.v14i1.41491

Received on 19 April 2021

Accepted on 28 October 2021

\begin{abstract}
Rental tax is an important source of revenue for local government units. After Nepal adopted fiscal federalism, concerns have been shown by policymakers as well as academicians on the fiscal sustainability of the local government units. In this context, this study attempts to explore tax compliance behaviour among rental income owners in Pokhara. The study is based on a survey of 196 households located in wards 9, 11 and 17 of Pokhara Metropolitan City. The wards represent commercial, semi-urban, and densely populated areas of the city respectively. The required data were gathered employing a self-administered questionnaire comprising Likert scales to measure tax awareness, attitude towards tax, cost of non-compliance, peer influence for compliance, government incentives, and tax compliance behavior of the rental income earner. The data collected were analyzed employing ANOVA, correlation and multiple regression. The research revealed a positive relationship between tax awareness, attitude towards tax, peer influence, and government incentives with tax compliances. The study findings depict that the taxpayers' awareness and perception towards tax are important variables that affect the compliance behavior of rental taxpayers. Moreover, the results reveal that the rental income earner in Pokhara does not comply with the tax rules due to the lower cost of non-compliance as negative relationship established was found between tax compliance and the cost of noncompliance. Metropolitan tax authority needs to focus on awareness and government incentives rather than the cost of non-compliance for better adherence to tax rules among rental taxpayers.
\end{abstract}

Keywords: Attitude towards tax, cost of non-compliance, government incentives, tax compliance, tax knowledge

\section{INTRODUCTION}

Compliances of rental tax rules play a vital role in the collection of government revenue. Timely submission of tax returns and payments of the actual amount of tax is the best practice of rental tax compliances for rental income earners. Tax compliance is the taxpayers' willingness to obey tax laws to obtain the economic equilibrium of a country (Andreoni et al., 1998). It is the

* Mr. Tiwari is an Assistant Professor at School of Business, Pokhara University.

Email: gtiwari104@gmail.com 
practice of exact reporting of financial information and their source and use of funds under the prevailing rules. Tax compliance levels have steadily remained low, even after the use of sanctions like penalties, armed monitoring, routine audits, and other similar actions, but not ample progress in tax revenue collection (Karimi et al., 2017). Although tax revenue is the major source of government revenue in every nation, Geremew (2017) found that with regard to factors affecting rental income taxpayers compliance revealed that educational status, confidence in tax assessment and collection procedure has significant relation with compliance behaviour of rental income earner. McBarnet (2001) recommended that tax compliance should be apparent in three ways, namely; a) committed compliance - taxpayers' willingness to pay taxes without complaint; b) capitulate compliance - reluctantly giving in and paying taxes and c) creative compliance engagement to reduce taxes by taking advantage of possibilities to redefine income and deduct expenditures within the bracket of tax laws. In developing countries, tax non-compliance is a serious challenge faced by income tax administration hindering tax revenue performance. Even though various tax reforms are undertaken by the government to increase tax revenue over the years, previous statistical evidence shows that the contribution of income tax to the government's total revenue to gross domestic product (GDP) share is low and is comparatively decreasing (Alabede et al., 2011). According to Thananga et al., (2013) the insight of landowners on rental income taxation and the tax administration was negative, as a result, it influenced their noncompliance behaviour, Taxpayers do not consider the implementation of tax rules in good faith. Tax knowledge and their compliances behaviour have positive relationship between different groups of income tax payer in Nepal (Poudel, 2017).

Nepal, like any other developing country, has inadequate capacity for tax administration. In Nepal, the income tax act focused self-assessment system for payment of tax, people think an unfair and less transparent system with non-believing government expenditure encourage poor compliance with tax rules. However, the cost of non-compliances creates fear to comply with the tax rules. Nepal adopted fiscal federalism, municipalities and other local government units have concerns for fiscal sustainability with their sources of income and most of the households of Pokhara earn somehow rental income. In this context rental income is one of the major sources of revenue for metropolitan cities. The study explores the tax compliance behaviour among rental income earners in Pokhara Metropolitan City, and to accomplish the factors that influence the tax compliance behaviour of rental income earners from house and other rented property in Pokhara Metropolitan City, Nepal. The study analyzes the relationship between determinants of rental tax compliance behaviour among rental income earners in Pokhara, Nepal.

\section{REVIEW OF LITERATURE}

Allingham and Sandmo (1972) proposed a model of tax evasion that assesses the individual's decision of filling in a tax return under the uncertainty of being audited in a static framework. If the taxpayer chooses to declare less than his real income, he is uncertain about his outcome due to the probability of being non-compliance. The model focuses that the taxpayer will escape from taxes if the probable value from evasion exceeds then the expected utility from full compliances. Yaniv (2009)attempted to clarify the mathematics behind Allingham and Sandmo's model and found that the demand curve of tax compliance can assist as an instrument for predicting taxpayer's behaviour when other parameters change (i.e., audit probability, penalty rate). It is essential to encourage compliance using persuasive methods before resorting to costly deterrence techniques. If authorities embrace the principle of procedural justice in their interaction 
with taxpayer, they may be able to shape the compliance behaviour. If authority's sanctions and penalties are used as the first resort, it may cause the risk of undermining their legitimacy (Doyle et al., 2009)

Empirical evidence about the extent of rental income tax compliance is very limited in Nepal. Tax compliance behaviour for developing countries also depends upon the financial risk for non-compliance behaviour of income earners. Knowledge, quality of service, policy maker's role, pubic quality for utilization of tax and ethnic diversity are significant factors that positively influence for improvement of tax compliance and mitigation of tax obligation (Alabede et al., 2011). Generally, the perception of landlords on their tax obligation is negative, and the taxpayers comply with the rules only to use any alternative to evade taxes. Cost of compliance plays a significant role in complying with tax rules. Perception, knowledge and cost are the major components of rental income tax policy (Thannanga et al., 2013). Concerning gender, males are less compliant than female counterparts, and female taxpayers are more compliant in comparison with male taxpayers (Engida \& Baisa 2014). Demographic factors and determination of rental tax is a complex process because females are more compliant, age is associated with compliance behaviour, and unmarried people are more law-abiding than married ones (Marandu et al., 2015).With regards to the factors affecting rental tax compliance towards the individual taxpayer in Malaysia, tax knowledge, compliance cost and tax agents have a significant relationship with compliance of tax and found that the individuals used tax agents to comply with tax rather than having good knowledge of tax (Xin et al., 2015). Prior research found that the positive perception towards the tax increase the compliance behaviour, and awareness have a positive influence on perception, which encourage people to comply with tax rules. Awareness, attitude and behavioural intention have a positive relationship between cox compliance (Nurwanah, et al., 2018). According to Deyganto (2018) the education level of the taxpayer and competence of the tax authority are not significant factors of tax compliance, but gender, age, lack of tax knowledge, simplicity of tax system, awareness on penalty for evading tax, income level of the taxpayer and perception on tax rates are significantly correlated with voluntary compliance attitude. Tax compliance is one of the attentive factors for policymaker under which demographic factors are most important on compliances of tax rules (Alabede, 2014).

The results of the study show the following: (1) the attitude of the taxpayer has a positive and significant effect on the behavioural intention for tax compliance. The formation of a tax professional attitude to be compliance should be able to minimize the underpayment of taxes and increase the positive attitude of taxpayers on paying taxes for the welfare of society; (2) subjective norm has a positive and significant

As stated in the prior section, the key motif of the study is to examine the determinants of rental tax compliances behaviour of rental income earners in Pokhara Nepal. The variables of the study are recognized on the review of previous researches and a conceptual framework is developed. The structure that was established for conceptual framework on factors affecting tax compliances behaviour for rental income earners. Based on the review of prior empirical literature about variables affecting tax compliance were found to be tax awareness, attitude towards tax, peer influence, cost of non-compliance and government incentives for compliances of rental income earners which are shown in Figure 1. 


\section{Figure 1}

\section{Conceptual Framework}

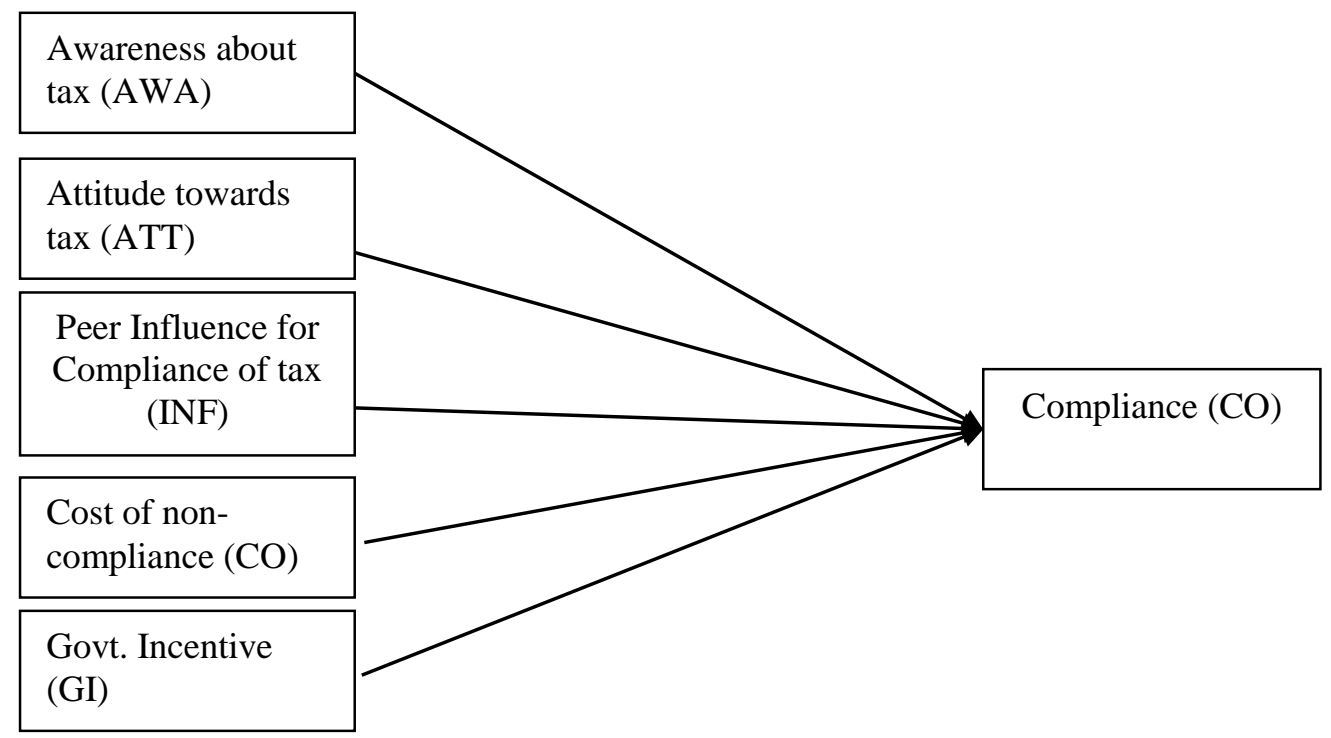

\section{METHODOLOGY}

This cross-sectional study examines the rental tax compliance behaviour of households in different wards of Pokhara city and identifies its determinants. Among 33 wards in the city, ward 9, 11 and 17 has been selected purposively as the sample wards to include representation of commercial area, semi-urban area and densely populated wards of Pokhara Metropolitan City. As per CBS (2011), there are 105,630 households in Pokhara city. Out of them, 196 households have been selected as a sample for the study employing Yamane (1967) sample size determination formula shown below using 93 percent confidence interval and 7 percent level of confidence.

$$
n=\frac{N}{1+N(e)^{2}}
$$

The data were obtained using a structured questionnaire distributed to the head of the households selected conveniently from the sample wards. The questionnaire developed for the study was separated into three parts: the first part contained knowledge of tax and different factors affecting rental tax compliances behaviour, the second part contained compliances behaviour of the taxpayer, and the third part included demographic information, which covers age, gender, education and the location of the taxpayer. Respondents were asked five points' Likert scale statements having strongly agreed, agreed, natural, less agreed, and not agreed. The collected data was analyzed using SPSS version 20. Descriptive statistics was employed for examining the demographic characteristics of the respondents. Furthermore, for identifying determinants of tax compliance behaviour correlation and multiple regression analysis has been undertaken. Variance Inflationary Factors (VIF) has been computed to assess the multicollinearity problem in the model. The OLS multiple regression model used in the study has the following specification:

$$
C O M_{i}=\alpha+\beta_{1} A W A_{i}+\beta_{2} A T T_{i}+\beta_{3} I N F_{i}+\beta_{4} C O_{i}+\beta_{4} G I_{i}+\varepsilon_{i}
$$

Where, $\mathrm{COM}=$ Tax Compliances

AWA = Awareness about tax 
ATT $=$ Attitude towards tax

$\mathrm{INF}=$ Peer Influence for Compliance of tax

$\mathrm{CO}=$ Cost of Non-Compliance

$\mathrm{GI}=$ Government Incentives

$\alpha=$ intercept term,

$\beta_{1}, \beta_{2} \ldots=$ Beta coefficients, and

$\varepsilon=$ residual term

\section{RESULTS AND DISCUSSION}

A total of 196 questionnaires were distributed across sample respondents in the study area, and quantitative data were collected for analysis.

\subsection{Respondents' Profile}

Table 1 exhibits the profile of the respondents from the selected sample households of the study. The majority of the respondents are found to be male (78.6 percent) with master's degree regarding their education (41.3 percent), the age group of 31 to 45 years (53.1 Percent ) and the highest participation(38.3 percent) of the respondents are from ward no 17 of Pokhara Metropolitan City.

\section{Table 1}

Descriptive Characteristics of the Respondents

\begin{tabular}{lcc}
\hline Gender Distribution of Respondents & & \\
\hline Particular & Frequency & Percent \\
Male & 154 & 78.6 \\
Female & 42 & 21.4 \\
Total & 196 & 100.0 \\
\hline Respondents' Location & & 36.2 \\
\hline Ward No 9 & 71 & 25.5 \\
Ward No 11 & 50 & 38.3 \\
Ward No 17 & 75 & 100.0 \\
Total & 196 & \\
\hline Education Status of Respondents & & 18.4 \\
Primary & 36 & 40.3 \\
Bachelor & 79 & 41.3 \\
Masters and above & 81 & 100.0 \\
Total & 196 & 6.1 \\
Age Distribution of Respondents & & 53.1 \\
18-30 Years & 12 & 29.6 \\
31-45 Years & 104 & 11.2 \\
46-55 Years & 58 & 100.0 \\
above 55 Years & 22 & \\
Total & 196 & \\
\hline Source: Field survey, 2019/20 and author'salculation & & \\
\hline
\end{tabular}

Source: Field survey, 2019/20 and author's calculation.

Out of the total respondent's majority $(78.6 \%)$ were male and only $24.4 \%$ were female. The high ratio of the male reflects the majority ownership structure of the property is held by the male in the study area. The majority of the respondents were located in ward no 17, which was followed by wards no 9 and 11, respectively. The higher number of households represents the 
higher sample of respondents. The number of respondents whose age between 31-45 years were $53.1 \%$, which is followed by the age between 46-55 years with $29.6 \%$. However, above 55 years was $11.2 \%$. Concerning the education level of the respondents, 41.3 percent were master's and above 40.3 percent were bachelor's degree, and 18.4 percent had the primary level of education, which indicates that the high ratio of respondents were educated. The respondents' response for the variable is indicated on five- points Likert scale with $1=$ strongly disagree and $5=$ strongly agree.

\section{Table 2}

Descriptive Statistics of Independent Variables

\begin{tabular}{llllll}
\hline Items & $\mathrm{N}$ & Min. & Max. & Mean & SD. \\
\hline Awareness about the Tax & 196 & 1.33 & 4.75 & 3.4496 & .68519 \\
Attitude towards the tax system & 196 & 1.83 & 4.33 & 3.1259 & .49761 \\
Cost of Non- Compliance & 196 & 2.33 & 5.00 & 3.3776 & .53192 \\
Government Incentives & 196 & 1.00 & 5.00 & 3.7245 & 1.01558 \\
Influence of Referred Group & 196 & 1.00 & 5.00 & 3.3469 & .86846
\end{tabular}

Source: Field survey, 2019/20 and authors' calculation

Table 2 exhibits descriptive statistics of factors influencing the compliances behaviour of rental income earners. Among them the awareness about tax rules, education and calculation skills of tax amount it has scored a mean of 4.44 with a standard deviation of 0.68519 . The result indicates that the respondents are aware of the tax rules, skills and techniques.

Similarly, the attitude towards the tax system of respondents has a mean score ranging from 2.15 to 3.88 , with an average 3.1259. A standard deviation of 0.497 indicates that the taxpayer has positive attitude for utilization of funds collected from the rental tax for economic growth and have attention for high-risk obligation and misuse of tax. About the cost of non-compliance, the mean values were 3.64 to 2.86 with the average mean score 3.377 , and the standard deviation is 0.5392 corresponding to the five points Likert scale value of five. It is found that if the government focused on levies for non-compliance of income tax rule, which discourage compliances under the self-assessment system. The lowest mean value was 2.86 which indicates that the respondents do not strongly agree that charges for non-compliance may not improve for tax rules compliance.

The result of government incentives for tax compliances by rental income earners agreed that government incentives such as a periodic waiver, discounts etc. encourage tax compliance. Among the respondents, $23.5 \%$ strongly agreed, and $40.3 \%$ agreed with the statement. The average mean score of the response is 3.7245 with a standard deviation of 1.015.

The influence of the referred group mean value scale is 3.28 to 3.42 , and the average mean score is 3.3469 with a standard deviation 0.8684 . The result indicates that the respondents were more influenced by their friends and financial obligation for tax compliance. The mean value of such influences is 3.42. Similarly, peers and family also have influenced for submission of rental tax of property owners of Pokhara Metropolitan City. The result indicates that the factor referred group influence for tax compliances behaviour of rental income earner for payment of tax. 


\section{Table 3}

Descriptive Statistics of Tax Compliance

\begin{tabular}{llllll}
\hline Items & $\mathrm{N}$ & Min & Max & Mean & Sd \\
\hline $\begin{array}{l}\text { Non-compliances with nil or incorrect return to avoid the } \\
\text { penalties }\end{array}$ & 196 & 1 & 5 & 2.47 & 1.139 \\
$\begin{array}{l}\text { Compliances by fair payment of tax as per income tax act } \\
\text { I pay tax because I feel that taxation is an obligation to the }\end{array}$ & 196 & 1 & 5 & 3.88 & 1.082 \\
citizen
\end{tabular}

Source: Field survey, 2019/20 and author's calculation.

Table 3 indicates that the highest mean value 4.19, represents the taxpayer lawfully comply the rules because they were aware and feel that the payments of tax are the compulsory obligation with the citizen in the country. Similarly, fair payments mean values of 3.88 represents compliances by the taxpayer as per their income level. Non-compliance with nil return 2.47 is the compliances for fairness, not for avoiding the tax fine and penalties. Overall results indicate that the taxpayer positive attitude for compliance with tax rules.

\section{Table 4}

Compliances Behaviour of Taxpayer

Respondents Having Permanent Account Number (PAN)

\begin{tabular}{lcc}
\hline & Frequency & Percent \\
Yes & 139 & 70.9 \\
No & 57 & 29.1 \\
Total & 196 & 100.0 \\
\hline Timely Submission of Income Tax Return & & \\
\hline Yes & 146 & 74.5 \\
No & 50 & 25.5 \\
Total & 196 & 100.0 \\
\hline Self-Submission of Income Tax Return & & \\
\hline Ownself (property Owner) & 128 & 65.3 \\
Tenant (Property User) & 68 & 34.7 \\
Total & 196 & 100.0 \\
\hline
\end{tabular}

Source: Field survey, 2019/20 and author's calculation.

Table 4 shows that $70.9 \%$ of the property owner have their PAN, which represents better compliance of tax rules, followed by $29.1 \%$. The majority of the taxpayer $(74.5 \%)$ submits their tax return on given time but concerning the compliance of rules, it is not enough because the remaining $25 \%$ propose income tax return later on the due date. Similarly, $65.3 \%$ of property owners have paid their tax to the concerned authority on their own and the remaining $34.7 \%$ depend upon their property users. 


\subsection{Tax Compliance Behaviour by Location and Educational Status of Household Head}

The impact of variables has been conducted to find out the difference between mean scores. The result shows the significant impact of factors as per the location of the respondents by using ANOVA, in Table 4.

\section{Table 4}

One-Way Analysis of Location on Study Variables

\begin{tabular}{|c|c|c|c|c|c|c|}
\hline Variables & Factors & $\begin{array}{l}\text { Sum } \\
\text { Squares }\end{array}$ & Df & Mean Square & $\mathrm{F}$ & Sig. \\
\hline \multirow[t]{3}{*}{ Awareness } & Between Groups & 3.196 & 2 & 1.598 & 3.670 & $.027^{* *}$ \\
\hline & Within group & 83.589 & 192 & .435 & & \\
\hline & Total & 86.785 & 194 & & & \\
\hline \multirow[t]{3}{*}{ Attitude } & Between Groups & .070 & 2 & .035 & .140 & .869 \\
\hline & Within group & 48.214 & 193 & .250 & & \\
\hline & Total & 48.285 & 195 & & & \\
\hline \multirow{3}{*}{$\begin{array}{l}\text { Peer } \\
\text { Influence }\end{array}$} & Between Groups & .311 & 2 & .156 & .500 & .608 \\
\hline & Within group & 60.115 & 193 & .311 & & \\
\hline & Total & 60.426 & 195 & & & \\
\hline \multirow{3}{*}{$\begin{array}{l}\text { Cost of non- } \\
\text { compliance }\end{array}$} & Between Groups & .545 & 2 & .272 & .963 & .384 \\
\hline & Within group & 54.627 & 193 & .283 & & \\
\hline & Total & 55.172 & 195 & & & \\
\hline \multirow{3}{*}{$\begin{array}{l}\text { Government } \\
\text { incentives }\end{array}$} & Between Groups & 6.237 & 2 & 3.119 & 3.089 & $.048^{* *}$ \\
\hline & Within group & 194.885 & 193 & 1.010 & & \\
\hline & Total & 201.122 & 195 & & & \\
\hline \multirow[t]{3}{*}{ Compliance } & Between Groups & 5.162 & 2 & 2.581 & 8.689 & $.000 *$ \\
\hline & Within group & 57.336 & 193 & .297 & & \\
\hline & Total & 62.499 & 195 & & & \\
\hline
\end{tabular}

Source: Field survey, 2019/20 and author's calculation

*Indicates the coefficient is significant at 1 \% level of significance

**Indicates the coefficient is significant at $5 \%$ level of significance

It is found that there is a significant impact of location on compliance at a $1 \%$ level of significance. Similarly, there is a significant impact of location on awareness and government incentive at 5\% level of significance. Furthermore, there is no significant impact of location on attitude, influence and cost. The result is similar and supported to the prior study (Alabede, 2014).

\subsection{Impact of Education Level on Study Variables}

The impact of education level on study variables (awareness, attitude, influence, cost, government incentive and compliance) has been presented in the table by using ANOVA. Table 5 shows that there is a significant influence of education level on awareness and government incentive at $1 \%$ level of significance. Similarly, there is a significant impact of respondent's education level on compliance at 5\% level of significance. Likewise, there is a significant impact of the education level on Influence at a $10 \%$ level of significance. Furthermore, there is no 
significant impact of the education level on attitude and cost.

\section{Table 5}

One-Way Analysis of Education Level on Study Variables

\begin{tabular}{|c|c|c|c|c|c|c|}
\hline \multirow{2}{*}{$\begin{array}{l}\text { Variable } \\
\text { Awareness }\end{array}$} & \multirow{2}{*}{$\begin{array}{l}\text { Factor } \\
\text { Between Groups }\end{array}$} & \multicolumn{2}{|c|}{ Sum of Squi df } & \multirow{2}{*}{$\begin{array}{c}\text { Mean Square } \\
4.494\end{array}$} & \multirow{2}{*}{$\begin{array}{c}\mathrm{F} \\
11.090\end{array}$} & \multirow{2}{*}{$\begin{array}{l}\text { Sig. } \\
.000^{*}\end{array}$} \\
\hline & & 8.987 & 2 & & & \\
\hline & Within group & 77.798 & 192 & .405 & & \\
\hline & Total & 86.785 & 194 & & & \\
\hline \multirow[t]{3}{*}{ Attitude } & Between Groups & 1.106 & 2 & .553 & 2.262 & .107 \\
\hline & Within group & 47.179 & 193 & .244 & & \\
\hline & Total & 48.285 & 195 & & & \\
\hline \multirow[t]{3}{*}{ Peer Influence } & Between Groups & 1.731 & 2 & .865 & 2.845 & $.061 * * *$ \\
\hline & Within group & 58.696 & 193 & .304 & & \\
\hline & Total & 60.426 & 195 & & & \\
\hline \multirow[t]{3}{*}{$\begin{array}{l}\text { Cost of non- } \\
\text { compliance }\end{array}$} & Between Groups & .874 & 2 & .437 & 1.553 & .214 \\
\hline & Within group & 54.298 & 193 & .281 & & \\
\hline & Total & 55.172 & 195 & & & \\
\hline \multirow[t]{3}{*}{$\begin{array}{l}\text { Government } \\
\text { incentives }\end{array}$} & Between Groups & 11.780 & 2 & 5.890 & 6.004 & $.003 *$ \\
\hline & Within group & 189.342 & 193 & .981 & & \\
\hline & Total & 201.122 & 195 & & & \\
\hline \multirow[t]{3}{*}{ Compliance } & Between Groups & 2.690 & 2 & 1.345 & 4.340 & $.014 * *$ \\
\hline & Within group & 59.809 & 193 & .310 & & \\
\hline & Total & 62.499 & 195 & & & \\
\hline
\end{tabular}

Source: Field survey, 2019/20 and author's calculation

*Indicates the coefficient is significant at $1 \%$ level of significance

**Indicates the coefficient is significant at $5 \%$ level of significance

***Indicates the coefficient is significant at $10 \%$ level of significance

\subsection{Factors Influencing Rental Tax Compliance Behaviour}

The study employs a correlation to investigate the relationship between different variables related to tax compliance. Correlation matrix output has been presented in Table 6 . The finding reveals the correlation between the compliance and all the independent variables are positively correlated except cost. The results also suggest that correlations within different components are low. The highest correlation is between attitude, and awareness and the lowest correlation is between compliance and cost. The result also reveals that the correlation coefficient of awareness and government incentive is significant at a 1 percent level of significance with compliance, and attitude is significant at 5 percent level of significance with compliance. 
Table 6

Correlation Between Dependent and Independent Variables

\begin{tabular}{|c|c|c|c|c|c|c|}
\hline & Awareness & Attitude & Influence & Cost & Govt. Incentive & Compliance \\
\hline Awareness & 1 & - & - & - & - & - \\
\hline Attitude & $\begin{array}{l}.418^{* *} \\
(.000)\end{array}$ & 1 & - & - & - & - \\
\hline Influence & $\begin{array}{c}.080 \\
(.264)\end{array}$ & $\begin{array}{c}.047 \\
(.512)\end{array}$ & 1 & - & - & - \\
\hline Cost & $\begin{array}{c}.071 \\
(.325)\end{array}$ & $\begin{array}{l}.250^{* *} \\
(.000)\end{array}$ & $\begin{array}{c}.080 \\
(.264)\end{array}$ & 1 & - & - \\
\hline Govt. Incentive & $\begin{array}{l}.351^{\text {** }} \\
(.000)\end{array}$ & $\begin{array}{l}.284^{* *} \\
(.000)\end{array}$ & $\begin{array}{l}.239^{* * *} \\
(.001)\end{array}$ & $\begin{array}{l}.181^{*} \\
(.011)\end{array}$ & 1 & - \\
\hline Compliance & $\begin{array}{l}.310^{* *} \\
(.000)\end{array}$ & $\begin{array}{l}.177^{*} \\
(.013)\end{array}$ & $\begin{array}{c}.089 \\
(.217) \\
\end{array}$ & $\begin{array}{r}-.129 \\
(.071)\end{array}$ & $\begin{array}{l}.213^{\text {** }} \\
(.003)\end{array}$ & 1 \\
\hline
\end{tabular}

Source: Field Survey, 2019/20 and author's calculation

*Indicates the coefficient is significant at $5 \%$ level of significance

** Indicates the coefficient is significant at $1 \%$ level of significance

The significant effect of study variables has been measured with the help of regression analysis. The model I, II, III and IV represent the multiple regressions respondent from ward no. 9, ward no 11, ward no 17 and all three wards were considered. The summary of the relationships between the variables are presented in Table 7.

\section{Table 7}

Overview of Multiple Regression Analysis

\begin{tabular}{lcccc}
\hline Item & $\begin{array}{l}\text { Model I } \\
\text { (Ward no. 9) }\end{array}$ & $\begin{array}{l}\text { Model II } \\
\text { (Ward no. 11) }\end{array}$ & $\begin{array}{l}\text { Model III } \\
\text { (Ward no 17) }\end{array}$ & $\begin{array}{l}\text { Model IV } \\
\text { All }\end{array}$ \\
\hline Constant & 2.051 & 2.209 & 4.377 & 2.788 \\
Awareness (AWA) & 0.186 & $0.475^{*}$ & -0.057 & $0.205^{*}$ \\
Attitude (ATT) & 0.210 & -0.115 & $0.241^{* *}$ & 0.098 \\
Influence (INF) & $0.190^{* * *}$ & 0.023 & -0.154 & 0.050 \\
Cost (CO) & -0.214 & -0.046 & $-0.277^{*}$ & $-0.208^{*}$ \\
Govt. Incentives (GI) & 0.032 & 0.038 & 0.047 & $0.071^{* * *}$ \\
Correlation Coefficient (R) & 0.439 & 0.523 & 0.465 & 0.384 \\
Coefficient of Determination $\left(\mathrm{R}^{2}\right)$ & 0.193 & 0.274 & 0.216 & 0.148 \\
F value & $3.058^{* *}$ & $3.319 * *$ & $3.801 *$ & $6.578^{*}$ \\
\hline
\end{tabular}

Source: Field Survey, 2019/20 and author's calculation

*Indicates the coefficient is significant at $1 \%$ level of significance

**Indicates the coefficient is significant at $5 \%$ level of significance

$* * *$ Indicates the coefficient is significant at $10 \%$ level of significance

$\mathrm{COM} \mathrm{I}=2.051+0.186 * \mathrm{AWA}+0.210 * \mathrm{ATT}+0.190 * \mathrm{INF}-0.214 * \mathrm{CO}+0.032 * \mathrm{GI}$

$\mathrm{COM}$ II $=2.209+0.475 * \mathrm{AWA}-0.115 * \mathrm{ATT}+0.023 * \mathrm{INF}-0.046 * \mathrm{CO}+0.038 * \mathrm{GI}$

$\mathrm{COM}$ III $=4.377-0.057 * \mathrm{AWA}+0.241 * \mathrm{ATT}-0.154 * \mathrm{INF}-0.277 * \mathrm{CO}+0.047 * \mathrm{GI}$

$\mathrm{COM}$ IV $=2.778+0.205 * \mathrm{AWA}+0.098 * \mathrm{ATT}+0.050 * \mathrm{INF}-0.208 * \mathrm{CO}+0.071 * \mathrm{GI}$

The result shows ward no nine compliances and all independent variables except cost move in a positive direction. Only one variable Influence has a t-value of 0.190 , which is significant at 10 percent level of significance. Similarly, the correlation coefficient is 0.439 . 
Coefficient of determination is 0.193 , which indicates that 19.3 percent variation in Compliance is explained due to selected independent variables. The $\mathrm{F}$ value is 3.058 , and it is significant at 5 percent level of significance. Similarly, in ward no 11 compliance and all independent variables except Attitude and Cost move in positive direction. Awareness is significant at 1 percent level of significance. Likewise, the correlation coefficient is 0.523 . The coefficient of determination is 0.274 which, indicates that 27.4 percent variation in Compliance is explained due to selected independent variables. The $\mathrm{F}$ value is 3.319 and it is significant at 5 percent level of significance. The regression result of ward no 17 indicates that compliance and all independent variables except Awareness, influence, and cost move in positive direction. Cost is significant at 1 percent level of significance and Attitude is significant at 5 percent level of significance. Similarly, the correlation coefficient is 0.465 . The coefficient of determination is 0.216 which indicates that 21.6 percent variation in Compliance is explained due to selected independent variables. The $F$ value is 3.801, and it is significant at 1 percent level of significance. Result three words in model IV indicates that compliance and all independent variables except cost move in positive direction. Awareness and Cost is significant at 1 percent level of significance and Government Incentive is significant at 10 percent level of significance. Similarly, the correlation coefficient is 0.384 . and the coefficient of determination is 0.148 . The $\mathrm{F}$ value is 6.578 and it is significant at 1 percent level of significance. This indicates that the multiple regressions, when the respondent from all three wards was considered, is fit to explain the relationship between the five independent variables and compliance. The computed values of all VIF are found to be less than 5 indicating absences of multi collinearity problem in the estimated model.

\section{CONCLUSION}

Though tax determinants have been an academic research topic in many developed countries in the world and tax compliance behaviour about rental income, has not been paid comprehensive attention in Nepal. The study revealed that rental income earner within Pokhara Metropolitan City The survey showed that taxpayers had a negative attitude towards tax evasion due to their adequate knowledge about tax laws and their implication on the daily life of the public. Similarly, it was found that peers and family had a positive influence on compliance with the rental tax of property owners of Pokhara Metropolitan City. Furthermore, fines and penalties encourage non-compliance with the rental income tax obligations. The respondents agreed that government incentive such as periodic waver, discounts etc. encourage them for maintaining their tax compliance behaviour.

The research revealed a positive relationship between tax awareness, attitude towards tax, peer influence, government incentives and tax compliances. More importantly, there was a high degree of relationship among perspective, awareness and tax compliance. It is supported with the prior research finding and the conclusion, it was found education status and trust in the tax system plays most significant relationship with tax compliance than other factors (Geremew, 2017). This study supports that the focus of equity theory and procedural justice theory of taxation if authority's sanctions and penalties used as the first resort, it may cause of the risk of undermining their legitimacy (Thibaut\& Walker, 1975). The study also supports Deyganto (2018) that the awareness and education towards tax are significantly correlated with voluntary compliance of tax rules.

To encourage compliance behaviour of taxpayer increasing awareness, government incentives and developing a positive attitude towards tax is more significant than charging penalties. The cost of non-compliance or charging penalties has negative correlation with the compliance behaviour of the taxpayers 
Awareness and perception towards tax mostly affected the compliance behaviour of taxpayers, thus, it can be concluded that there was positive relationship established between independent variables and compliance with tax laws. It is also found that, a negative relationship is established between tax compliance and the cost of non-compliance therefore the property owners do not comply with the tax rules due to the cost of non-compliance. Similarly, when the individual ward and the entire wards were considered, the output of regression analysis indicated that there was a significant relationship between all the independent variables and tax compliances. This indicated that selected independent variable such as awareness, attitude, cost, peer influence and government incentives play an important role in determining tax compliance.

Various steps and approaches are required to increase the compliance of rules. Generally, understanding the compliances factors by the authorities play a significant role in developing the strategies for better adherence to tax rules. Pokhara Metropolitan City should increase the awareness program among the community, which will play the positive role in the development of good perception and positive attitudes towards the tax and improve the timely submission of the rental tax return. Government incentives play significant roles rather than charging fines and penalties to the taxpayers in the self-assessment system. Authorities should consider such factors while implementation of the rules. There should be regular interaction between rental taxpayers and authorities so that the knowledge will increase, the perception will be positive and compliances behaviour will increase to the taxpayers.

\section{ACKNOWLEDGEMENT}

The author is thankful to Pokhara University Research Centre (PURC) for providing the research grant on this topic. This paper is a part of the same research. The author is the faculty of the School of Business, Pokhara University and is also grateful for managing the environment for research activity.

\section{REFERENCES}

Alabede, J. (2014). An exploratory analysis of individual taxpayers compiance behaviour in Nigeria: A study of demographic differnces and impact in Nigeria. International Journal of Accounting and Taxation, 2(2), 39-48.

Alabede, J. O., Ariffin, Z. Z., \& Idris, K. M. (2011). Determinants of tax compliance behaviour: A proposed model for Nigeria. International Research Journal of Finance and Economics, 78(1), 121-136.

Allingham, M. G., \& Sandmo, A. (1972). Income tax evasion: A theoretical analysis. Taxation: Critical Perspectives on the World Economy, 3, 323-338.

Andreoni, J., Erard, B., \& Feinstein, J. (1998). Tax compliance. Journal of Economic Literature, 36(2), 818-860.

Deyganto, K. O. (2018). Factors influencing taxpayers' voluntary compliance attitude with tax system: Evidence from Gedeo zone of Southern Ethiopia. Universal Journal of Accounting and Finance, 6(3), 92-107.

Doyle, E., Gallery, K., Coyle, M., \& Commissioners, I. R. (2009). Procedural justice principles and tax compliance in Ireland: A preliminary exploration in the context of reminder letters. Journal of Finance and Management in Public Services, 8(1), 49-62

Engida, T. G., \& Baisa, G. A. (2014). Factors influencing taxpayers' compliance with the tax system: An empirical study in Mekelle City, Ethiopia. eJTR, 12, 433. 
Geremew, D. A. B. A. (2017). Factors affecting rental income tax payers compliance with tax system: In case of Hawassa City Administration, Snnprs, Ethiopia. Research Journal of Finance and Accounting, 8(7), 35-43.

Karanja, E. K. (2014). Factors affecting voluntary tax compliance on rental income: a case study of Nairobi landlords (Doctoral dissertation, United States International UniversityAfrica).

Karimi, H., Maina, K. E., \& Kinyua, J. M. (2017). Effect of technology and information systems on revenue collection by the county government of Embu, Kenya. International Academic Journal of Information Systems and Technology, 2(1), 19-35.

Kirchler, E., Hoelzl, E., \& Wahl, I. (2008). Enforced versus voluntary tax compliance: The "slippery slope" framework. Journal of Economic psychology, 29(2), 210-225.

Marandu, E. E., Mbekomize, C. J., \& Ifezue, A. N. (2015). Determinants of tax compliance: A review of factors and conceptualizations. International Journal of Economics and Finance, 7(9), 207-218.

McBarnet, D. (2019). When compliance is not the solution but the problem: From changes in law to changes in attitude. Centre for Tax System Integrity (CTSI), Research School of Social Sciences, The Australian National University.

Nepal, C. B. S. (2011). National Population and Housing Census, National Report. Government of Nepal. Kathmandu.

Nurwanah, A., Sutrisno, T., Rosidi, R., \& Roekhudin, R. (2018). Determinants of tax compliance: theory of planned behavior and stakeholder theory perspective. Problems and Perspectives in Management, 16(4), 395-407.

Poudel, R. L. (2017). Tax knowledge among university teachers in Pokhara. Journal of Nepalese Business Studies, 10(1), 69-77.

Thananga, A. G., Wanyoike, D. M., \& Wagoki, A. J. (2013). Factors affecting compliance on rental income tax policy by landlords in Nakuru Municipality. Journal of Agriculture and Environmental Sciences, 2(1), 26-38.

Thibaut, J. W., \& Walker, L. (1975). Procedural justice: A psychological analysis. L. Erlbaum Associates.

Torgler, B. (2002). Speaking to theorists and searching for facts: Tax morale and tax compliance in experiments. Journal of Economic Surveys, 16(5), 657-683.

Usman, A. (2018). The determinants of tax compliance behavior among individual taxpayers in Gombe State, Nigeria (Doctoral dissertation, University Utara Malaysia).

Xin, M. K. H., Khai, K. G., Fong, L. S., \& Chen, N. H. (2015). Factors affecting individual taxpayers' compliance in Malaysian tax filing system. The International Journal of Business and Management, 3(9), 339.

Yamane, T. (1967). Statistics: An introductory analysis (2 $2^{\text {nd }}$ ed.). Harper \& Row.

Yaniv, G. (2009). The tax compliance demand curve: A diagrammatical approach to income tax evasion. The Journal of Economic Education, 40(2), 213-224. 